\title{
The impact of cardinal temperature variation on the germination of Haloxylon aphyllum L. seeds
}

\section{Mansour Taghvaei* and Masoumaeh Ghaedi}

Department of Desert Region Management, College of Agriculture, Shiraz University, Shiraz 7144165186, Iran

Seed germination is a biological process that is affected by a variety of genetic and environmental factors. The cardinal temperature and thermal time are required for germination. The principal objective of this study was to identify and characterize variations in the base, optimum, and maximum germination temperatures of Haloxylon aphyllum L. from two seed sources, in order to establish models for use in predicting seeding dates. Mature H. aphyllum seeds were germinated at temperatures between 5 and $35^{\circ} \mathrm{C}$. The germination behavior of $H$. aphyllum seeds to different temperature regimens in light was evaluated over a temperature range of $5-35^{\circ} \mathrm{C}$ at intervals of $5^{\circ} \mathrm{C}$. The rate of germination increased between base and optimum thermal conditions, and decreased between optimum and maximum thermal conditions; the germination rate varied in a linear fashion at both sub-optimal and supra-optimal temperatures. The linear regression fit the range of germination rates at $5^{\circ} \mathrm{C}$ to $25^{\circ} \mathrm{C}$ and $25^{\circ} \mathrm{C}$ to $30^{\circ} \mathrm{C}$, and thus the base temperature, optimum temperature, and maximum temperature for the germination of $H$. aphyllum were measured to be $0.6^{\circ} \mathrm{C}, 25.69^{\circ} \mathrm{C}, 37.90^{\circ} \mathrm{C}$, and $^{\circ}$ $1.76^{\circ} \mathrm{C}, 21.56^{\circ} \mathrm{C}, 37.90^{\circ} \mathrm{C}$ for Qom and the Fars dune desert respectively.

Key words: cardinal temperature, germination rate, Haloxylon aphyllum, seed germination

\section{INTRODUCTION}

Haloxylon aphyllum L. and Haloxylon persicum L. (family Chenopodiaceae) are leaf succulent dominant components of the vegetation predominating in sandy and clay deserts across Central Asia, from western China and Mongolia to the Caspian Sea (National Academy of Sciences 1980). These zones cover a total area of 1 million $\mathrm{km}^{2}$ across the Turanian deserts, and can also be found in the hot deserts of the Middle East. In the dune desert areas of Central Asia, forests of Haloxylon species perform a critical function in the restoration of land degradation. Orlovsky and Birnbaum (2002) previously asserted that Haloxylon spp. are important for the control of desertification, by helping to fix shifting sands, increasing the biodiversity and biological productivity of arid and semi-arid zones, restoring degraded pastures and forests, and serving as a good source of fuelwood. The growth of ephemerals, annual, and shrub species occurs under closed Haloxylon canopies; hence, Haloxylon forests generate sustainable quantities of edible biomass for the grazing of domestic and wildlife species throughout the year. The principal objectives of this study were to characterize some pasture reclamation technologies in dune deserts, as well as methods utilized to improve rangelands in sandy and dune deserts, and to determine the ecological role of Haloxylon species in Central Asian deserts (Orlovsky and Birnbaum 2002, Huang et al. 2003). Haloxylon aphyllum is a xerophyte species; this quality makes it a useful plant in harsh environmental conditions, as it can adapt to drought, salinity, and poor nutritional conditions (Wu 1995, Huang et al. 2003). This plant (cc) This is an Open Access article distributed under the terms of the Creative Commons Attribution Non-Commercial License (http://creativecommons.org/licenses/by-nc/3.0/) which permits unrestricted non-commercial use, distribution, and reproduction in any medium, provided the original work is properly cited.
Received 29 December 2009, Accepted 31 March 2010

${ }^{*}$ Corresponding Author

E-mail: taghvaei@shirazu.ac.ir Tel: +98-711-613-8163 
can survive under the extremely harsh conditions pertaining in arid zones, from temperatures of -25 to $50^{\circ} \mathrm{C}$. H. aphyllum regenerates by seeding. The seeds begin to mature from late October until the first days of January. $H$. aphyllum seeds begin to germinate in these deserts in late February, and its leaves appear in May. In arid environments, the seedling is the most vulnerable stage in the plant life cycle, and germination determines when seedling growth begins (Gutterman 1993). Seed germination performs an important function in the regeneration of plant species, particularly under arid and unpredictable environmental conditions, most notably those of Mediterranean ecosystems (Gimmenez-Benavides et al. 2005). The germination responses of species to environmental parameters determine their distribution in arid environments. Several environmental factors function as determining factors in germination (Bewley and Black 1994); seed germination is affected by light, temperature, and a host of other environmental factors (Bewley and Black 1994, Baskin and Baskin 1998). Among these factors, temperature is a crucial factor governing the maximum germination percentage (Heydecker 1977) and germination rate (Flores and Briones 2001, Phartyal et al. 2003). It has been recognized since as early as 1860 that three cardinal temperatures (minimum, optimum, and maximum) described the temperature range over which the seeds of a particular species can germinate (Bewley and Black 1994). Seeds of each species possess the capacity to germinate over a defined temperature range, which is referred to as the cardinal temperature (Alvarado and Bradford 2002). Finally, the cardinal temperature (minimum or basic temperature, optimum, and maximum) is the temperature range within which the seeds of a particular species can germinate. The minimum cardinal temperature is the lowest temperature at which crop growth can occur; this temperature is referred to as the base temperature $\left(\mathrm{T}_{\mathrm{b}}\right)$, and no growth occurs below that temperature. The optimum cardinal temperature $\left(\mathrm{T}_{0}\right)$ is the temperature at which crop growth and performance are at their maximum. Finally, the maximum cardinal temperature $\left(T_{m}\right)$ is the highest temperature at which plant growth can occur (Alvarado and Bradford 2002). Finally, growth and development processes are optimal when the temperature is between the minimum and maximum bounds of the range, and close to the optimum cardinal temperature. There are clear minimum and maximum temperatures for germination, and within the broad range between them all seeds can germinate. Seed germination begins at the minimum temperature and the germination rate increases with increasing temperature to the optimum, and then decreases with further rises in temperature to the maximum (Bewley and Black 1994). Some methods have been developed previously to describe species growth data (e.g. germination percentage, germination rate) in response to temperature, but among those methods the germination rate method is the most specifically salient to temperature (Covell et al. 1986), and a great deal of previous research has been done in efforts to understand these relations; regression analysis is generally recognized as the best statistical tool for the investigation of relationships among these variables. The data collected at sub-optimal and supra-optimal temperatures were used to construct two linear regressions to describe the increases and decreases in the germination rate at sub-optimal and supra-optimal temperatures, respectively. The optimum temperature is the temperature at which these two lines intersect (Covell et al. 1986). Roberts (1988) previously described a model elucidating the relationship between germination rate and temperature. The influence of temperature on germination rate and thermal time in plant species has been previously evaluated by a variety of researchers, including the common crupina (Crupina vulgaris Pers.) (Shafii and Price 2001), Himalayan elm (Ulmus wallichiana) (Phartyal et al. 2002), lentil seeds (Ellis and Barrett 1994), Kochia Scoparia L. (Al-Ahmadi and Kafi 2007), pumpkin (Cucurbita pepo) (Zehtab-Salmasi 2006). H. aphyllum is one of the predominant halophytic species in the salt dune desert surrounding Qom, Iran. Cardinal temperatures are critically important to the germination stage and seeding date. Ghaedi et al. (2009) reported that no significant differences were observed between light and darkness in terms of the seed germination rates of H. aphyllum, and the highest percentage of germination was observed at $25^{\circ} \mathrm{C}$ under light and dark conditions. However, no research has yet been conducted regarding the germination responses of H. aphyllum to cardinal temperature. The primary objective of this investigation, then, was to evaluate the relationship between the temperature and germination rate for two seed lots of H. aphyllum, and to estimate the values of base $\left(\mathrm{T}_{\mathrm{b}}\right)$, optimum $\left(\mathrm{T}_{\mathrm{o}}\right)$, and maximum $\left(\mathrm{T}_{\mathrm{m}}\right)$ temperatures for them. Our methodology was designed to evaluate the variation in germination responses (H. aphyllum) to different temperatures, and to determine the seeding dates at which the soil temperature would be appropriate for optimal germination, and subsequent stand establishment in the field.

\section{MATERIALS AND METHODS}




\section{Plant material}

Mature seed lots of $H$. aphyllum were collected from two arid areas - the Qom dune desert $\left(34^{\circ} 27^{\prime} 26^{\prime \prime} \mathrm{N}\right.$, $51^{\circ} 10^{\prime} 1 " \mathrm{E}$ ) and the Fars (Neirize) dune desert (29³ $35^{\prime} \mathrm{N}$, $\left.54^{\circ} 00^{\prime} \mathrm{E}\right)$. Provenances located at elevations of 877.4 and $1,632 \mathrm{~m}$ a.s.l with different weather (Tables 1 and 2) in the southwest and center of Iran, in the Asian desert. Iran is located in the mid-latitude belt containing the earth's arid and semi-arid regions. Approximately $60 \%$ of Iran is classified as either arid or semi-arid; much of the country has a desert climate, with an average annual precipitation of less than $300 \mathrm{~mm}$ (Mansoory 1992).

After eliminating humidity, the seeds were stored in bags in a refrigerator $\left(5^{\circ} \mathrm{C}\right)$ until the beginning of each experiment. This study was conducted at the Department of Desert Region Management, College of Agriculture, University of Shiraz, Iran. The seeds were treated with $0.2 \%$ Benomil fungicide prior to the germination test. In all experiments, four replications of 50 seeds of two provenances were sown at $5,10,15,20,25$, and 30 on Whatman No. 1 filter paper, in Petri dishes (50-mm diameter) under light conditions (Ghaedi et al. 2009). The filter paper was moistened with approximately $5 \mathrm{~mL}$ of demonized water, allowing about half of the seeds to be immersed in the solution. During this experiment, lost water was replaced when necessary. The seeds were considered to have germinated when the emerging radical was over 5-mm long (Young et al. 1981). The numbers of germinated seeds were recorded on a daily basis. After nine days, the final number of germinated seeds was calculated, as well as the percentage of germination. The mean time to full germination was calculated in accordance with the equation developed by Ellis and Roberts (1981). The germination rate was calculated by the inverse of mean time to full germination (Tobe et al. 2000, Flores and Briones 2001).

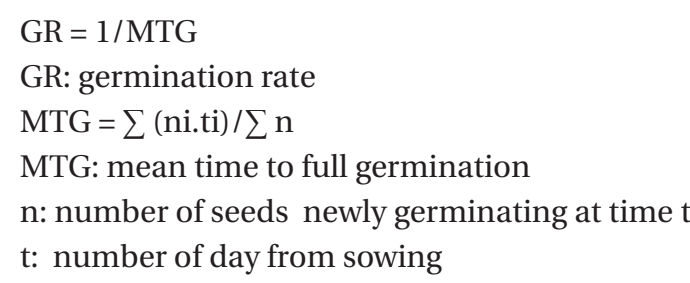

Cardinal temperature was calculated on the basis of the responses of germination rate to temperature (Villalobos et al. 2002). We employed an intersecting-line model (Hadley et al. 1983, Kocabas et al. 1999, Phartyal et al. 2003, Al-Ahmadi and Kafi 2007). The $\mathrm{T}$ base and $\mathrm{T}$ maximum were derived from the intersection of each regression line with the abscissa, and the $\mathrm{T}$ optimum was calculated from the intersection of two linear regression lines of the germination rate at sub-optimal and supraoptimal temperatures (Covell et al. 1986).

\section{Data analyses}

Data were checked for normality and then analyzed using MSTATC statistical software (MStatC Inc., East Lansing, MI, USA). Treatment means were separated by Dun-

Table 1. Average of maximum, minimum of temperature and monthly average of total of precipitation of the Fars dune desert

\begin{tabular}{|c|c|c|c|c|c|c|c|c|c|c|c|c|c|}
\hline & Jan & Feb & Mar & Apr & May & Jun & Jul & Aug & Sep & Oct & Nov & Dec & Annual \\
\hline $\begin{array}{l}\text { Maximum } \\
\text { temperature } \\
\left({ }^{\circ} \mathrm{C}\right)\end{array}$ & 12.3 & 15.6 & 20.1 & 25.7 & 31.3 & 35.8 & 37.3 & 36.8 & 33.3 & 27.8 & 19.7 & 14.8 & 25.9 \\
\hline $\begin{array}{l}\text { Minimum } \\
\text { temperature } \\
\left({ }^{\circ} \mathrm{C}\right)\end{array}$ & 2.2 & 4.2 & 8 & 12.5 & 16.4 & 2.8 & 23.9 & 22.6 & 18.9 & 13.7 & 8 & 4.6 & 13 \\
\hline $\begin{array}{l}\text { Precipitation } \\
(\mathrm{mm})\end{array}$ & 66.9 & 23.6 & 25.4 & 11.1 & 0.5 & 0.6 & 3.4 & 2.1 & 0 & 0.7 & 9.2 & 61.4 & 204.9 \\
\hline
\end{tabular}

Table 2. Average of maximum, minimum of temperature and monthly average of total of precipitation of the Qom dune desert

\begin{tabular}{|c|c|c|c|c|c|c|c|c|c|c|c|c|c|}
\hline & Jan & Feb & Mar & Apr & May & Jun & Jul & Aug & Sep & Oct & Nov & Dec & Annual \\
\hline $\begin{array}{l}\text { Maximum } \\
\text { temperature } \\
\left({ }^{\circ} \mathrm{C}\right)\end{array}$ & 10.5 & 13.4 & 18.3 & 26 & 31.6 & 37.8 & 40.1 & 39.4 & 34.9 & 27.4 & 18.8 & 12.3 & 25.9 \\
\hline $\begin{array}{l}\text { Minimum } \\
\text { temperature } \\
\left({ }^{\circ} \mathrm{C}\right)\end{array}$ & -1.5 & 0.1 & 4.5 & 10.3 & 15.1 & 20 & 23 & 21.1 & 15.4 & 9.9 & 4 & -0.1 & 10.2 \\
\hline $\begin{array}{l}\text { Precipitation } \\
(\mathrm{mm})\end{array}$ & 25.9 & 21.7 & 28.1 & 19.6 & 11.8 & 1.4 & 0.9 & 0.4 & 0.5 & 6.3 & 15.2 & 19.3 & 151.1 \\
\hline
\end{tabular}


can's test in cases in which the F value of the treatments was significant at probability levels of 0.05 or 0.01 .

\section{RESULTS}

\section{Qom dune desert seed source}

The germination rate differed significantly among temperature treatments $(P<0.01)$. In the first 120 hours, the response of germination to temperature differed completely. The seeds germinated rapidly at $25^{\circ} \mathrm{C}$ and then reached their peak of germination (Fig. 1), but the percentage of germinated seeds was lower at $5^{\circ} \mathrm{C}$ and $10^{\circ} \mathrm{C}$ than at $15^{\circ} \mathrm{C}$ and $25^{\circ} \mathrm{C}$, the germination percentage

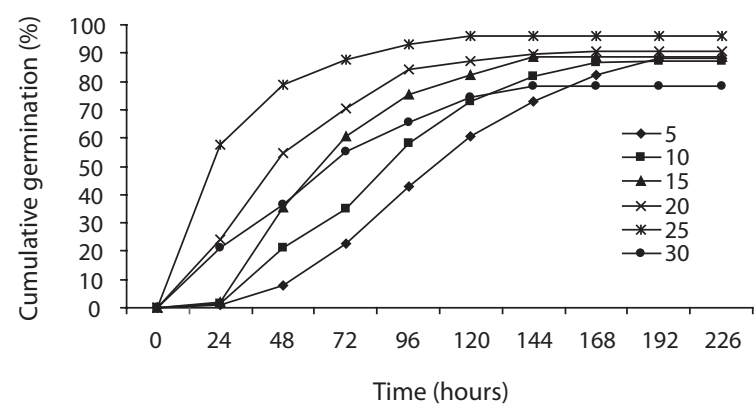

Fig. 1. The trend of cumulative germination responses of seeds to temperature at 24 hours intervals at $5^{\circ} \mathrm{C}, 10^{\circ} \mathrm{C}, 15^{\circ} \mathrm{C}, 20^{\circ} \mathrm{C}, 25^{\circ} \mathrm{C}$, and $30^{\circ} \mathrm{C}$. Each point represents the mean of 4 replications (200 seeds).

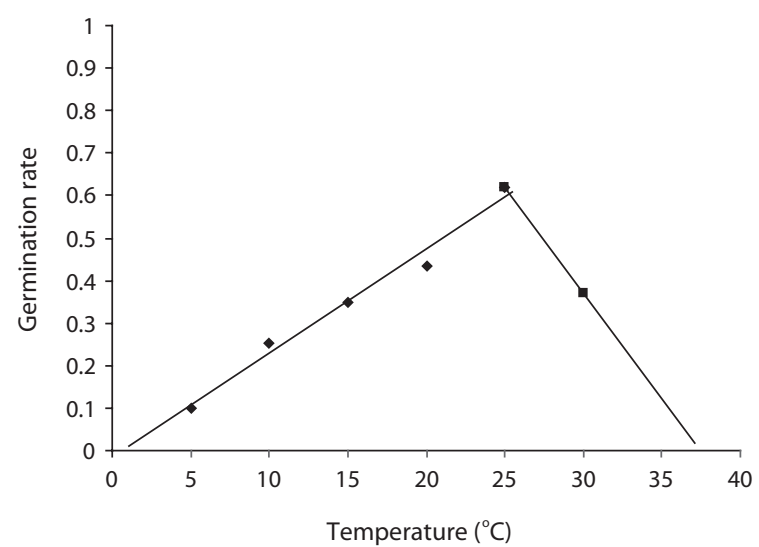

Fig. 2. Haloxylon aphyllum germination rate response to temperature in the Qom dune desert seed source. of seeds reached $96 \%$ at $25^{\circ} \mathrm{C}$ after 24 hours, but the germination percentage of seeds reached $60.5 \%$ at $5^{\circ} \mathrm{C}$ after 120 hours, and the germination percentage of seeds reached $74.5 \%$ at $30^{\circ} \mathrm{C}$ after 120 hours.

The germination rate evidenced an increasing trend from $5^{\circ} \mathrm{C}$ to $25^{\circ} \mathrm{C}$ and the germination rate decreased abruptly with increases in temperature. The highest and lowest germination rates were noted at $25^{\circ} \mathrm{C}$ and $30^{\circ} \mathrm{C}$, respectively (Fig. 2). The germination rate was 0.1 at $5^{\circ} \mathrm{C}$ and reached 0.62 at $25^{\circ} \mathrm{C}$, and then decreased to 0.37 at $30^{\circ} \mathrm{C}$ (Fig. 2). The drawn-to-fit linear scale to cumulative normal distribution evidenced a positive slope from $5^{\circ} \mathrm{C}$ to $25^{\circ} \mathrm{C}$ and a negative slope from $25^{\circ} \mathrm{C}$ to $30^{\circ} \mathrm{C}$. The intersection of fit linear regressions between $5^{\circ} \mathrm{C}$ to $25^{\circ} \mathrm{C}$ and between $25^{\circ} \mathrm{C}$ to $30^{\circ} \mathrm{C}$ with the abscissa showed a $\mathrm{T}$ base of 0.62 and a T maximum of 37.9, respectively (Table 3 ). The intersection of two linear regression lines of the rate of germination at sub-optimal and supra-optimal temperatures revealed the optimal temperature (25.69) (Table 3).

\section{Fars dune desert seed source}

The germination rate was shown to be affected significantly by the temperature treatments $(P<0.01)$. The germination response differed completely at different temperatures. During the first 120 hours, the seeds germinated more rapidly at $20^{\circ} \mathrm{C}$ than other temperature treatments, and reached a germination peak (Fig. 3), but seed germination was slower at $5^{\circ} \mathrm{C}, 10^{\circ} \mathrm{C}$ and $15^{\circ} \mathrm{C}$. The germination percentage of seeds at $20^{\circ} \mathrm{C}$ reached $60 \%$ after 120 hours, but the germination percentage of seeds reached $55 \%$ after 192 hours at $5^{\circ} \mathrm{C}$ and never reached a level of $60 \%$. Seeds germinated slowly at $30^{\circ} \mathrm{C}$, reaching a level of $48 \%$ after 120 hours, and did not increase with time until 226 hours.

The germination rate increased with increasing temperature. The highest seed germination rate $(0.5)$ was obtained at $25^{\circ} \mathrm{C}$. The germination rates were 0.1 and 0.5 at $5^{\circ} \mathrm{C}$ and $20^{\circ} \mathrm{C}$, respectively, and decreased to 0.3 at $25^{\circ} \mathrm{C}$ (Fig. 4). We noted no significant differences in germination rates between $5^{\circ} \mathrm{C}$ and $10^{\circ} \mathrm{C}$, and between $15^{\circ} \mathrm{C}$ and $30^{\circ} \mathrm{C}$. The highest positive slope of germination was not-

Table 3. Equation calculated cardinal temperature for Haloxylon aphyllum L. seeds

\begin{tabular}{ccccc}
\hline Seed source & Equations $<$ op & Equations $>$ op & $\mathbf{T}_{\mathbf{b}}\left({ }^{\circ} \mathbf{C}\right)$ & $\mathbf{T}_{\mathbf{o}}\left({ }^{\circ} \mathbf{C}\right)$ \\
\hline Qom & $\mathrm{GR}=0.024 \mathrm{~T}-0.015$ & $\mathrm{GR}=-0.049 \mathrm{~T}+1.861$ & 0.62 & 37.9 \\
Fars & $\mathrm{GR}=0.026 \mathrm{~T}-0.046$ & $\mathrm{GR}=-0.039 \mathrm{~T}+1.291$ & 1.76 & 25.69 \\
33.10 & 21.56
\end{tabular}

$G R$, germination rate; $T$, temperature; $T_{b}$, base temperature; $T_{0}$, optimum temperature; $T_{M}$, maximum temperature. 


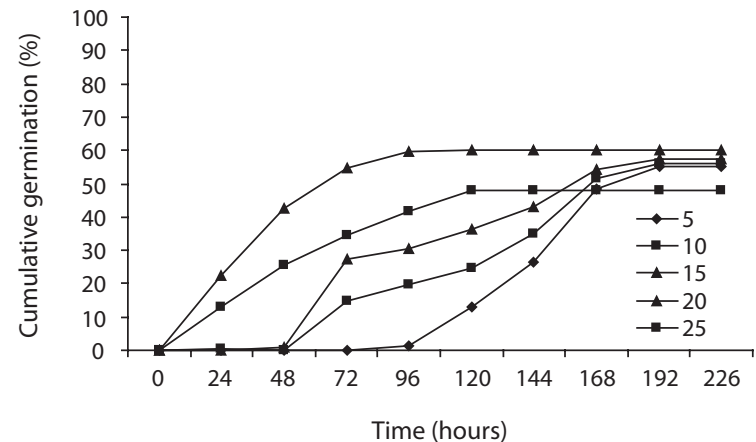

Fig. 3. The trend of cumulative germination response of to temperature at 24 hours intervals at $5^{\circ} \mathrm{C}, 10^{\circ} \mathrm{C}, 15^{\circ} \mathrm{C}, 20^{\circ} \mathrm{C}, 25^{\circ} \mathrm{C}$. Each point represents the mean of 4 replications (200 seeds).

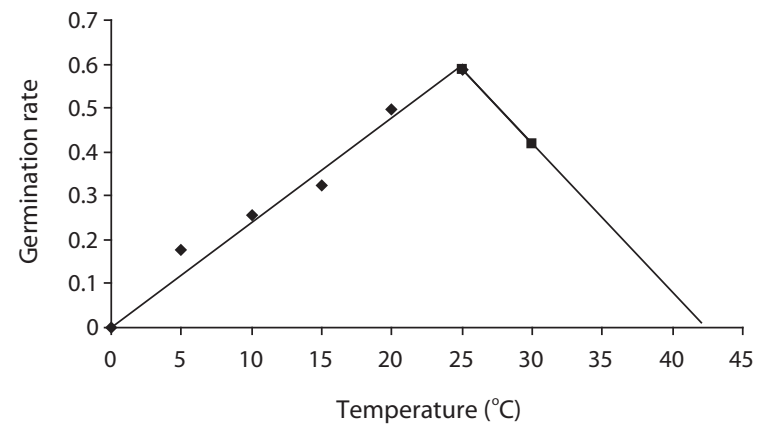

Fig. 4. Haloxylon aphyllum germination rate response to temperature in the Fars dune desert seed source

ed at $25^{\circ} \mathrm{C}$; however, it was reduced at $30^{\circ} \mathrm{C}$ (Table 3). The fitted regression line to the germination rate evidenced a positive slope between $5^{\circ} \mathrm{C}$ and $20^{\circ} \mathrm{C}$ and a negative slope between $20^{\circ} \mathrm{C}$ and $30^{\circ} \mathrm{C}$. The intersection of fit linear regression between $5^{\circ} \mathrm{C}$ and $20^{\circ} \mathrm{C}$ and between $20^{\circ} \mathrm{C}$ and $30^{\circ} \mathrm{C}$ with the abscissa showed a $\mathrm{T}$ base of 1.76 and a $\mathrm{T}$ maximum of 33.10, respectively (Table 3 and Fig. 4). The intersection of the two linear regression lines of the germination rate at sub-optimal and supra-optimal revealed the optimal temperature (21.56) (Table 3 and Fig. 4)

\section{DISCUSSION}

Seed germination is a complex process that is profoundly affected by environmental factors, particularly cardinal temperature (minimum temperature, optimum, and maximum temperatures). Our results demonstrated that seed germination is influenced by temperature. Many authors have previously reported this in their studies (Phartyal et al. 2002, Zehtab-Salmasi 2006). A positive linear relationship was shown to exist between temperature and the germination rate from $5^{\circ} \mathrm{C}$ to $20^{\circ} \mathrm{C}$ and $25^{\circ} \mathrm{C}$, and a negative linear relationship was detected from $20^{\circ} \mathrm{C}$ to $25^{\circ} \mathrm{C}$ and $25^{\circ} \mathrm{C}$ to $30^{\circ} \mathrm{C}$ (Figs. 1 and 2); Kamkar et al. (2006) reported identical results in a previous study of the germination rate responses of three millet species to temperature (ranging from 5 to $45^{\circ} \mathrm{C}$ with $5^{\circ} \mathrm{C}$ interval). Ghaedi et al. (2009) reported that the optimal temperature for the germination of $H$. aphyllum was $25^{\circ} \mathrm{C}$, and confirmed that germination increased until $30^{\circ} \mathrm{C}$. Continuing the linear regression of germination rate and sub-optimal and supra-optimal temperatures ultimately revealed the base temperature and maximum temperature for $H$. aphyllum. Shafii and Price (2001) estimated the cardinal temperatures for the common crupina (Crupina vulgar$i$ Pers) with a linear regression of the germination rate and the sub-optimal and supra-optimal temperatures. Hardegree (2006) predicted the cardinal temperatures of germination for four rangeland grass species using a regression method. Arnold (1959) generated a model via the direct measurement of germination rates at constant temperature, and confirmed the base temperature in a linear heat unit system based on the sub-optimal thermal behavior of germination seeds and their relationships to temperature. The cardinal temperatures for germination have been determined via the use of germination rate for different plants (Kamkar et al. 2006, Al-Ahmadi and Kafi 2007, Gilbertson and Johnson 2008, Rizzardi et al. 2009). The seeds of different provenances differed in terms of their cardinal temperatures. The response to temperature depends on the species, variety, growing region, seed quality, and duration of time from harvesting (Lawrence 2001). As a general rule, temperate-region seeds require lower temperatures than tropical region seeds, and wild species have lower temperature requirements than domesticated plants (Ali et al. 2008). The range in base temperature between the provenances was $0.62^{\circ} \mathrm{C}$ and $1.76^{\circ} \mathrm{C}$, but was not statistically significant, although it may be biologically significant (Table 1). The maximum temperature differed between the two seed provenances. The maximum temperatures were 37.9 and 33.1 in the Qom and Fars dune desert regions, respectively (Table 1). Ali et al. (2008) reported the variation in base and maximum temperature requirements for germination among different wheat (Triticum aestivum) genotypes. The cardinal temperatures for germination are related, generally, to the environmental range of adaptation of a given species, and serve to help match germination timing to favorable conditions for the subsequent growth and development of seedlings.

\section{CONCLUSION}


We believe that the seeds harvested from the Qom dune desert evidenced greater vigor than those harvested from the Fars dune desert, as the maximum germination rate in the seeds harvested from Qom dune was 96, and the maximum germination rate in the seeds from the Fars dune desert was 60 . High-quality seeds can germinate under broader temperature ranges than low-quality seeds. The base temperatures of $0.62^{\circ} \mathrm{C}$ and $1.76^{\circ} \mathrm{C}$ for Haloxylon seeds from the Qom dune desert and the Fars dune desert, respectively, make it possible to directly sow seeds at the end of winter in wet soil, after winter precipitation. However, it is not possible to sow seeds early in the Qom dune desert, where the spring is hotter than it is in the Fars dune desert. Maximum temperature limits the time during which effective sowing can occur, because the higher soil and air temperatures in spring limit the germination rates of Haloxilon seeds, and also markedly attenuate seedling vigor. The maximum temperatures in the Qom dune desert and the Fars dune desert were 37.9 and 33.1, respectively (Table 1). Thus, the time required for germination in the Qom dune desert is longer than that of the Fars dune desert. This information will enable producers to time Haloxilon seeding when soil temperatures are optimal for germination and the establishment of seedlings.

\section{LITERATURE CITED}

Al-Ahmadi MJ, Kafi M. 2007. Cardinal temperatures for germination of Kochia scoparia (L.). J Arid Environ 68: 308314.

Ali ZI, Mahalakshmi V, Singh M, Ortiz-Ferrara G, Peacock JM. 2008. Variation in cardinal temperatures for germination among wheat (Triticum aestivum) genotypes. Ann Appl Biol 125: 367-375.

Alvarado V, Bradford KJ. 2002. A hydrothermal time model explains the cardinal temperatures for seed germination. Plant Cell Environ 25: 1061-1069.

Arnold CY. 1959. The determination and significance of the base temperature in a linear heat unit system. J Am Soc Hortic Sci 74: 430-445.

Baskin CC, Baskin JM. 1998. Seeds: Ecology, Biogeography, and Evolution of Dormancy and Germination. Academic Press, San Diego, CA.

Bewley JD, Black M. 1994. Seeds: Physiology of Development and Germination. Plenum Press, London.

Covell S, Eliss RH, Roberts EH, Summerified RJ. 1986. The influence of temperature on seed germination rate in grain legumes: I. A comparison of chickpea, lentil, soya- bean and cowpea at constant temperatures. J Exp Bot 37: 705-715.

Ellis RH, Barrett S. 1994. Alternating temperatures and rate of seed germination in lentil. Ann Bot 74: 519-524.

Ellis RH, Roberts EH. 1981. The quantification of ageing and survival in orthodox seeds. Seed Sci Technol 9: 373-409.

Flores J, Briones O. 2001. Plant life-from and germination in a Mexican inter-tropical desert: effects of soil water potential and temperature. J Arid Environ 47: 485-497.

Ghaedi M, Taghvaei M, FallahShamsi SR, Niazi A. 2009. The influence of light, temperature and salinity on seed germination of Haloxylon aphyllum L. Sci Res J Iranian Range Manage Soc 2: 411-420.

Gilbertson PK, Johnson BL. 2008. Cardinal temperatures for borage seed germination. 2008 Joint Annual Meeting, 2008 Oct 5-9, Houston, Texas.

Gimmenez-Benavides L, Escudero A, Perez-Garcia F. 2005. Seed germination of high mountain Mediterranean species: altitudinal, interpopulation and interannual variability. Ecol Res 20: 433-444.

Gutterman Y. 1993. Seed Germination in Desert Plants: Adaptations of Desert Organisms. Springer-Verlag, Berlin.

Hadley P, Roberts EH, Summerfield RJ, Minchin FR. 1983. A quantitative model of reproductive development in cowpea [Vigna unguiculata (L) Walp.] in relation to photoperiod and temperature, and implications for screening germplasm. Ann Bot 51: 531-543.

Hardegree SP. 2006. Predicting germination response to temperature: I. Cardinal-temperature models and subpopulation-specific regression. Ann Bot 97: 1115-1125.

Heydecker W. 1977. Stress and seed germination: an agronomic view. In: The Physiology and Biochemistry of Seed Dormancy and Germination (Khan AA, ed). Elsevier/North Holland and Biomedical Press, Amsterdam, pp 237-282.

Huang ZY, Zhang XS, Zeng GH, Gutterman Y. 2003. Influence of light, temperature, salinity and storage on seed germination of Haloxylon ammodendron. J Arid Environ 55: 453-464.

Kamkar B, Koocheki A, Nassiri Mahallati M, Rezvani Moghaddam P. 2006. Cardinal temperatures for germination in three Millet Specieses (Panicum miliaceum, Pennisetum glaucum and Setaria italica). Asian J Plant Sci 5: 316-319.

Kocabas Z, Craigon J, Azam-Ali SN. 1999. The germination response of Bambara groundnut (Vigna sublerrannean (L)Verdo) to temperature. Seed Sci Technol 27: 303-313.

Lawrence OC. 2001. Principles of Seed Science and Technology. $4^{\text {th }}$ ed. Kluwer Academic Publishers, Norwell, MA.

Mansoory M. 1992. A Directory of Wetland in Middle Est. 
Ramsar Sites Information Service, Wageningen.

National Academy of Sciences. 1980. Firewood Crops: Shrub and Tree Species for Energy Production. National Academy of Sciences, Washington, DC.

Orlovsky N, Birnbaum EH. 2002. The role of Haloxylon species for combating desertification in Central Asia. Plant Biosystems 136: 233-240.

Phartyal SS, Thapliyal RC, Nayal JS, Joshi G. 2002. Processing of seed to improve seed lot quality of rare and endangered tree species of Himalayan maple (Acer caesium Wall. Ex. Brandis) and Elm (Ulmus wallichiana Planchon). Seed Sci Technol 30: 371-382.

Phartyal SS, Thapliyal RC, Nayal JS, Rawat MMS, Joshi G. 2003. The Influences of temperatures on seed germination rate in Himalayan elm (Ulmus wallichiana). Seed Sci Technol 31: 83-93.

Rizzardi MA, Luiz AR, Roman ES, Vargas L. 2009. Effect of cardinal temperature and water potential on Morning Glory (Ipomoea triloba) seed germination. Planta Daninha 27: 13-21.
Roberts EH. 1988. Temperature and seed germination. In: Plants and Temperature: Symposia of the Society of Experimental Biology (Long SP, Woodward FI, eds). Company of Biologist Ltd., Cambridge, pp 109-132.

Shafii B, Price WJ. 2001. Estimation of cardinal temperatures in germination data analysis. J Agric Biol Environ Stat 6: 356-366.

Tobe K, Li X, Omasa K. 2000. Seed germination and radicle growth of a halophyte, Kalidium capsicum (chenopodiaceae). Ann Bot 85: 391-396.

Villalobos FJ, Mateos L, Orgaz F, Fereres E. 2002. Fitotecnia. Bases y Technología de la Producción Agrícola. MundiPrensa, Madrid.

Wu ZY. 1995. Vegetation of China. Science Press, Beijing. (in Chinese)

Young JA, Evans RA, Stevens R, Everett RL. 1981. Germination of Kochia prostrata seed. Agron J 73: 957-961.

Zehtab-Salmasi S. 2006. Study of cardinal temperatures for Pumpkin (Cucurbita pepo) seed germination. J Agron 5: 95-97 